\title{
Laffer-görbék Magyarországra*
}

\author{
Gábriel Péter - Kaszab Lóránt
}

Tanulmányunkban egy, a magyar gazdaságra kalibrált általános egyensúlyi modell segítségével megbecsüljük a munkát terhelő adókulcs Laffer-görbéjét. Eredményeink alapján a költségvetési bevételeket középtávon maximalizáló adókulcs 55 százalék, míg a humántöke-felhalmozást is figyelembe vevő, az adócsökkentés hosszabb távú hatásait is megragadó modellváltozat alapján 40 százalék. Szimulációink szerint a válság elötti magas adóterhelés csökkentése középtávon közel 80 százalékban, míg hosszabb távon teljes mértékben önfinanszírozó. További adócsökkentések esetén az önfinanszírozás aránya az alacsonyabb induló adókulccsal összhangban valamelyest ugyan mérséklődik, de továbbra is magas.

Journal of Economic Literature (JEL) kódok: E0, E13, E2, E3, E62, H0, H2, H3, H6

Kulcsszavak: Laffer-görbe, fiskális politika, munkát terhelő adókulcs, adócsökkentés, humán tőke, önfinanszírozás

\section{Bevezetés}

A fiskális politikai döntések minőségét javítja, ha kellő pontossággal számszerűsíthetők a döntések következményei. Az adópolitika területén a döntéshozatalt érdemben támogathatja a Laffer-görbe ismerete ${ }^{1}$, mely megadja, hogy az adókulcs változtatása összességében hogyan változtatja meg a költségvetés bevételeit. Az adókulcs változtatása számos csatornán hat a gazdaság növekedésére és ezáltal a költségvetési bevételekre, így az adókulcs-változtatás költségvetési bevételekre gyakorolt hatásának teljeskörű számszerüsítése bonyolult. A becsléseknek új lendületet adott, hogy egyre több országban váltak elérhetővé részletes adatbázisok az adóalanyokról. Ezek segítik annak feltérképezését, hogy az adóintézkedések hatásai milyen csatornákon keresztül jelentkeznek. A jobb minőségű adatok mellett a Laffer-görbe-becslések azért is újra előtérbe kerültek, mivel hozzájárulhatnak

* A jelen kiadványban megjelenő írások a szerzők nézeteit tartalmazzák, ami nem feltétlenül egyezik a Magyar Nemzeti Bank hivatalos álláspontjával.

Gábriel Péter a Magyar Nemzeti Bank föosztályvezetője. E-mail: gabrielp@mnb.hu

Kaszab Lóránt a Magyar Nemzeti Bank közgazdasági kutatási szakértője. E-mail: kaszabl@mnb.hu

A szerzők köszönetet mondanak Baksay Gergelynek, Berta Dávidnak, Bögöthy Zoltánnak, Erdélyi Leventének, Szabó Lajosnak és a két anonim bírálónak értékes észrevételeikért. A fennmaradó hibák a szerzőket terhelik. A magyar nyelvű kézirat első változata 2019. szeptember 23-án érkezett szerkesztőségünkbe.

DOI: http://doi.org/10.25201/HSZ.18.4.5576

${ }^{1}$ A Laffer-görbe első említése Wanninski (1978) írásában jelenik meg. 
a szélesebb szakmai és a közvéleményt érdeklő gazdaságpolitikai viták eldöntéséhez.

A pénzügyi válság kitörését és a globális gazdaság visszaesését követően fontos kérdés volt, hogy milyen mértékben érdemes fiskális stimulust alkalmazni a gazdaság ösztönzésére. Gazdasági visszaesés esetén a fiskális politika hatása a növekedésre jellemzően nagyobb, ami önmagában aktívabb fiskális beavatkozás mellett szólt. Ugyanakkor a válságban az államadósság finanszírozhatóságának fenntarthatósága is középpontba került. Az adócsökkentésen keresztül végrehajtott gazdaságösztönzés fenntarthatósága jelentős mértékben függ attól, hogy az adócsökkentés milyen hosszabb távú hatásokat generál a gazdaságban. Amennyiben például egy adott gazdaságban a munkát terhelő adókulcs csökkentésének hatására a munkakínálat jelentősen nő, azaz a munkát terhelő adókulcs közel van a Laffer-görbe csúcsához, akkor az adócsökkentés nagymértékben önfinanszírozó, így az adócsökkentést követően hosszabb távon nem merülnek fel államadósság-fenntarthatósági problémák.

Ebben a tanulmányban a munkát terhelő adókulcsra felírt Laffer-görbéket számítunk egy Magyarországra kalibrált általános egyensúlyi modell segítségével. A magyar adószerkezet az elmúlt évtizedben jelentősen átalakult. Az adóbevételeken belül csökkent a munkát, és nőtt a fogyasztást terhelő adóbevételek súlya. A magyar gazdaságra számszerűsített Laffer-görbe hozzájárul az elmúlt időszakban végrehajtott és potenciális jövőbeli adópolitikai intézkedések hatásának számszerúsítéséhez. Tanulmányunkban számszerüsítjük a 2007-2011 között végrehajtott munkát terhelő adó csökkentésének, valamint egy további potenciális adócsökkentésnek a következményeit. Bemutatjuk, hogy a múltbeli adócsökkentések nagymértékben önfinanszírozók voltak, s egy további adócsökkentés költségvetési hatását is érdemben tompítják a gazdaság növekedéséből és fehéredéséből fakadó többletbevételek.

\section{Irodalom-összefoglaló}

A költségvetési adóbevételt maximalizáló munkát terhelő adóráta, valamint a Laffer-görbe empirikus becslése rendkívül nehéz feladat. Ennek egyik oka, hogy a rendelkezésre álló idősorokban országonként az adóráták egy korlátos intervallumban változnak, amely a bevételt maximalizáló adórátát jellemzően nem tartalmazza. Másrészt a munkát terhelő adóráta változásának hatása számos tényezőtől függhet, például a többi adóráta mértékétől és országspecifikus tényezőktől, melyekre nehéz megfelelően kontrollálni. Harmadrészt az összbevételre gyakorolt hatás egy része nem közvetlenül a munkát terhelő adóbevételeken, hanem közvetetten a fogyasztási és tőke-adóbevételeken keresztül jelentkezhetnek, melyek nehezen becsülhetők.

A fenti nehézségekre tekintettel az empirikus tanulmányok többsége a munkát terhelő adókulcs változásának a munkát terhelő adó adóalapjára gyakorolt hatására fókuszál. Jellemzően egy adott országban egy adott időpontban megváltozott adó- 
szabályok adóalanyokra gyakorolt heterogén hatását felhasználva határozzák meg az adóalap adókulcsra, illetve a foglalkoztatás adókulcsra vonatkozó rugalmasságát. Feldstein (1995) az USA-ra, Kleven és Schultz (2014) Dániára, Jongen és Stoel (2019) pedig Hollandiára vonatkozóan végzett becsléseket. A becsült rugalmasságok többnyire 0,2-0,3 körüli értékeket vettek fel, azaz az adóráta 1 százalékpontos csökkentése jellemzően 0,2-0,3 százalékkal növelte meg a munkát terhelő adó adóalapját. Emellett a felsorolt tanulmányok fontos kontribúciója, hogy rámutattak arra, hogy az adókulcs változtatásának adóalapra gyakorolt hatása a foglalkoztatottság változása mellett jelentős részben az adóoptimalizálás, illetve adóelkerülés mértékének változásán keresztül jelentkezik. Adókulcsemelés hatására emelkedik az egyéni vállalkozók száma, nagyobb arányban élnek az adófizetők az adórendszer biztosította kedvezményekkel, valamint megnő az eltitkolt jövedelmek aránya.

Saez et al. (2012) részletezi, hogy a mikroadatbázisok felhasználásával becsült elaszticitások milyen feltételezések mellett nyújtanak elégséges információt az adóbevételt maximalizáló adóráta kiszámításához. A szükséges feltételezések közül több meglehetősen restriktív, például az, hogy a munkát terhelő adóráta csak a saját adóalapjára hat, és az is, hogy a becsült rugalmasság nem függ az adóráta mértékétől. Ezzel együtt viszonylag elterjedt a becsült rugalmasságok használata a bevételt maximalizáló adóráta meghatározásához. A becsült elaszticitások alapján jellemzően magas, 70-80 százalékpontos adókulcsok mellett éri el az adóbevétel a maximumát.

Akgun et al. (2017) 34 ország 1978 és 2014 közötti adatai alapján végzett becsléseket az adókulcs változtatásának adóbevételekre gyakorolt hatásáról. A több ország adatait használó megközelítés abból a szempontból előnyös, hogy flexibilisebb függvényforma mellett is megbecsülhetővé teszi a Laffer-görbét. A becslés alapján a munkát terhelő adókból származó bevétel 50-70 százalékpontos adókulcs mellett éri el a maximumát. A tanulmány továbbá arra is rámutatott, hogy a munkát terhelő adó progresszivitásának növelése az adóbevételeket szignifikánsan csökkenti. A becslések ugyanakkor bizonytalanok, különböző specifikációk mellett jelentősen változik az adóbevételt maximalizáló adókulcs mértéke.

A Laffer-görbe empirikus becslésének nehézségei miatt a görbe meghatározásához számos tanulmány makrogazdasági modelleket használ. A megközelítés előnye, hogy az adókulcs változtatásának hatása teljeskörüen és hosszabb időtávon is számszerüsíthető, valamint hogy a modellek gazdaságpolitikai lépések hatásának szimulációjára is alkalmasak.

Schmitt-Grohe és Uribe (1997) egy egyszerü üzleti ciklus modellt tanulmányoz, ahol a kormányzat kizárólag a munkát terhelő adók változtatásával egyensúlyozza ki a költségvetését minden periódusban. A két szerző megmutatja, hogy a Laffer-görbe kirajzolható egy ilyen típusú modellben. Azt találják továbbá, hogy a kiegyensúlyozott költségvetéssel múködő fiskális szabályok károsak lehetnek a gazdaságra, 
hiszen fellendülés idején alacsonyabb adókkal és magasabb kormányzati költekezéssel túlstimulálják a gazdaságot, míg recesszióban adóemeléssel és a kiadások visszafogásával súlyosbítják a helyzetet.

Ireland (1994), valamint Novalez és Ruiz (2002) endogén növekedést tartalmazó modellben vizsgálja az adócsökkentés adóbevételekre gyakorolt hatását. Eredményeik alapján az adócsökkentésnek a humán tőke felhalmozásának ösztönzése következtében jelentős a növekedési hatása, emiatt hosszabb távon sem válik szükségessé az adókulcs korrigálása a költségvetési egyensúly fenntartása érdekében.

Floden és Lindé (2001) a kormányzati transzferek jóléti hatását vizsgálta egy Svédországra és egy USA-ra kalibrált heterogén szereplős modellben, melyben az egyének idioszinkratikus, egyénileg nem biztosítható termelékenységi sokkokkal szembesülnek. A jólétet maximalizáló adóráták mellett számszerűsítik az adóbevételeket maximalizáló adórátákat is. Eredményeik alapján a munkát terhelő adók esetén a Laffer-görbe csúcsa az 50 százalékos kulcs környékén van. Emellett azt találták, hogy a Laffer-görbe alakja elsősorban a munkakínálat elaszticitásától és a fogyasztási és tókét terhelő adókulcs szintjétől függ, minden más paraméter jelentősége másodlagos.

Trabandt és Uhlig (2011) az EU-14 és USA 1995-2007 időszakra illesztett Laffer-görbéjére végzett fiskális elemzéseket. Azt találták, hogy a munkát terhelő adókulcs csökkentése nagyobb mértékben önfinanszírozó az EU-14-ben, mint az USA-ban, mivel az EU-14-ben az átlagos effektív adókulcs közelebb van a Laffer-görbe csúcsához. Trabandt és Uhlig 2012-es tanulmánya már a 2010-ig tartó időszakra terjesztette ki az elemzést, és ezáltal lehetővé vált az európai szuverén adósságválság fiskális elemzése a Laffer-görbén keresztül. Eredményeikből az derült ki, hogy 2010-ben az európai gazdaságokban a fiskális kiigazítást célzó adóemeléseknek igen limitált volt az adóbevétel-növelő hatása.

Nutahara (2015) a Trabandt és Uhlig (2011; 2012) által leírt modellt alkalmazta a japán gazdaságra, és becsült Laffer-görbéket. Számításai szerint a munkát terhelő adóbevételt maximalizáló adóráta 50-60 százalékpont körül lehet. Azt találta továbbá, hogy mivel Japánban a tőkét terhelő adókulcs magas, valamint a munkát terhelő adókulcs viszonylag távol van a Laffer-görbe csúcsától, ezért a tőkeadó csökkentésének, valamint a költségvetési bevételcsökkenést ellensúlyozó munkát terhelő adókulcs-emelésnek összességében jelentős jólétnövelő hatása lehet.

Féve és szerzőtársai (2018) kibővítették Trabandt és Uhlig modelljét likviditáskorlátos háztartásokkal. Eredményeik alapján a Laffer-görbe alakja függ attól, hogy az adósság vagy a transzferek mértéke változik az adókulcs csökkentését követően. A Laffer-görbe alakjára vonatkozó eredményeik ugyanakkor elsősorban a negatív 
államadósságot feltételező forgatókönyvekben térnek el a korábbi tanulmányok számításaitól. Ebben az esetben a Laffer-görbe horizontális S alakúvá válik.

A jelen tanulmányban alapvetően a Trabandt és Uhlig (2011) tanulmányában használt modellt kalibráltuk Magyarországra a Laffer-görbe számszerűsítésének érdekében. A munkát terhelő adókulcs változtatásának elemzését a humántőke-felhalmozást lehetővé tevő modellváltozat segítségével is elvégeztük. Az empirikus tanulmányok tanulságait figyelembe véve az eredeti modellt kibővítettük, s expliciten beépítettük a munkát terhelő adókulcs-változtatás adóelkerülésre gyakorolt hatását. Meglátásunk szerint az így előállt modellváltozat minden olyan lényeges mechanizmust képes megragadni, amely a magyar gazdaságra becsült Laffer-görbe alakját érdemben befolyásolhatja.

\section{A magyar adóreform}

A Laffer-görbe meghatározása a magyar gazdaságpolitikai döntéshozatal szempontjából is releváns, mert segítségével számszerűsíthetők a már megvalósított korábbi, valamint a már bejelentett jövőbeli intézkedések hatásai.

A magyar adórendszer az elmúlt évtizedben jelentősen átalakult². 2010-ig a munkát terhelő adókat kiugróan magas adóterhelés és progresszivitás jellemezte. A magas adóék visszafogta a munkakínálatot, és a jövedelem eltitkolására ösztönzött. 2011-ben a kormányzat egykulcsos személyi jövedelemadót (SZJA) vezetett be, s a munkát terhelő adók progresszivitása az adójóváírás, a szuperbruttó adóalap, valamint a nyugdíjjárulék-plafon fokozatos kivezetését követően megszúnt. ${ }^{3} \mathrm{~A}$ gazdaság növekedésének támogatására érdekében a társasági nyereségadó kulcsa is mérséklődött, 2017-től kis- és nagyvállalkozások esetében egységesen 9 százalékra csökkent. A költségvetési egyensúly biztosítása érdekében a munkát terhelő és a társasági adók csökkentésével párhuzamosan az általános forgalmi adó emelkedett, valamint a kormányzat ágazati különadókat vezetett be a nagyobb teherviselő képességű szolgáltató ágazatokban. A fogyasztási adóbevételeket tovább növelték a gazdaság kifehérítése érdekében hozott kormányzati intézkedések. Az adószerkezet átalakításának köszönhetően az adóbevételeken belül a munkát terhelő adók aránya jelentősen mérséklődött, míg a fogyasztást terhelő adók súlya érdemben emelkedett (1. ábra).

Az adószerkezet átalakítása a korábban meghozott kormányzati döntéseknek megfelelően a jövőben is folytatódhat. A munkáltatók és munkavállalók képviselőivel kötött 2016. novemberi bérmegállapodást követően a kormányzat bejelentette, hogy 2022-ig a munkáltatói szociális hozzájárulási adót a 2016-os 27 százalékról

\footnotetext{
${ }^{2}$ A fontosabb lépéseket a Mellékletben soroltuk fel.

${ }^{3}$ A magyar adóreform lépéseit részletesen tárgyalja Baksay és Palotai (2017), valamint Matolcsy és Palotai (2018).
} 
fokozatosan 11,5 százalékra mérsékli, amennyiben a reálbérek emelkedésének üteme magas marad. A tervezett lépések további jelentős adószerkezet-átalakulást eredményezhetnek.

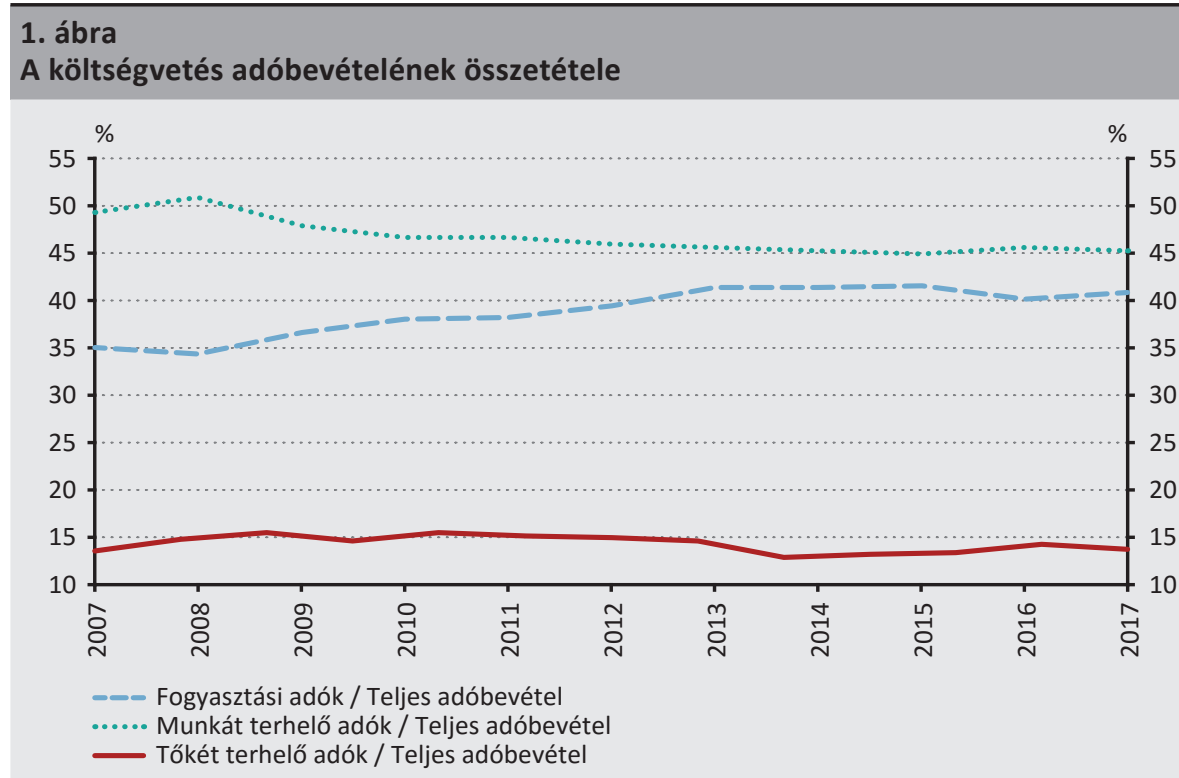

Forrás: MNB (2018)

\section{A modell}

A tanulmányunkban használt közgazdasági modell Trabandt és Uhlig (2011) tanulmányán alapul. Az eredeti modellt az adókulcsok szintje és a jövedelem eltitkolása közötti összefüggéssel bővítettük. Két modellváltozatot használunk, és mindkettő Trabandt és Uhlig (2011) tanulmányán alapul. Az egyikben a munkavállalók által ledolgozott óraszám jelenik meg inputként a termelési függvényben, azaz a humán tőke minőségét homogénnek és időben állandónak feltételezzük. A másik változatban lehetséges a humántőke-felhalmozás, így a termelés inputjaként a munkavállalók minősége is megjelenik. A modellben három szereplőt jelenítünk meg: háztartások, vállalatok és az állam.

\section{Háztartások}

A háztartás a következő hasznossági függvényt $(U)$ maximalizálja végtelen időhorizonton:

$$
E_{0} \sum_{t=0}^{\infty} \beta^{t}\left[U\left(c_{t}, n_{t}\right)\right]
$$


ahol $c_{t}$ és $n_{t}$ a fogyasztást és a ledolgozott munkaórákat jelöli. A fogyasztás és a szabadidő (amely a teljes időkeretből a munkaórák levonását követően marad) növeli a háztartás hasznosságát.

$\beta$ jelöli a diszkontfaktort, amely tipikusan nulla és egy közötti szám, és a háztartás türelmetlenségét ragadja meg: a háztartás a jelenbeni fogyasztást preferálja a jövőbenihez képest, vagyis a jövőbeni fogyasztást kisebb súllyal veszi figyelembe (diszkontálja). $E_{0}$ racionális várakozást jelöl, amit a fogyasztó a kezdeti, nulla peridusból előretekintve képez. A szumma jelölés $(\Sigma)$ azt ragadja meg, hogy a háztartás összegzi a jelen és jövőbeni (jelenre diszkontált) hasznosságát.

Trabandt és Uhlig (2011) nyomán a következő konstans Frisch-elaszticitású hasznosságfüggvényt használjuk:

$$
U\left(c_{t}, n_{t}\right)=\left\{\begin{array}{lr}
\frac{1}{1-\eta}\left\{c_{t}^{1-\eta}\left[1-\kappa(1-\eta) n_{t}^{1+1 / \varphi}\right]^{\eta}-1\right\}, & \text { amikor } \eta \neq 1 \\
\log \left(c_{t}\right)-\kappa n_{t}^{1+1 / \varphi}, & \text { amikor } \eta=1 .
\end{array}\right.
$$

Az előző egyenletben $\eta>0$ jelöli a kockázatkerülés mértékét (az inverze pedig az intertemporális helyettesítés rugalmassága), $\kappa$ egy paraméter, amit arra használhatunk, hogy beállítsuk a munkaidő, $n_{t}$ arányát ( 25 százalék) állandósult állapotban a teljes időkorláton belül, amit egységnyire normálunk. 1- $n_{t}$ jelöli a szabadidőt, míg $\varphi$ jelenti a munkakínálat Frisch-elaszticitását. A háztartás preferenciái megfelelnek a stabil növekedési pálya követelményeinek (lásd például King és Rebelo 1999). A fenti egyenlet második sora azt mutatja, hogy $\eta=1$ esetben a fogyasztás logaritmikus formában írható fel.

Az alapmodellben a munkából származó tényleges jövedelmet (bevallott plusz eltitkolt) a reálbér és a ledolgozott munkaórák szorzataként kapjuk $\left(w_{t} n_{t}\right)$.

Az alapmodellt kiegészíthetjük ún. második generációs humántőke-felhalmozással is Trabandt és Uhlig (2011) alapján. A humán tőkét a háztartások tanulással gyarapíthatják. A teljes időkeret egy részét munkára $\left(q_{t} n_{t}\right)$ és tanulásra $\left(1-q_{t}\right) n_{t}$, a maradékot pedig szabadidőre fordítják. A munkából származó jövedelem - a humántőke-felhalmozást is figyelembe véve - a következő módon írható fel:

$$
L_{t}=w_{t} h_{t-1} q_{t} n_{t}
$$

A humántőke-felhalmozás nélküli, ún. alapmodellt a fenti egyenletben a $h_{t-1} q_{t}=1$ restrikcióval kapjuk. 


\section{Progresszivitás}

Progresszív adózás bevezetéséhez a háztartásoknak különbözniük kell, amit a következő feltevésekkel ragadunk meg az állandósult állapotban. Feltesszük, hogy a háztartások a humán tőke tekintetében különböznek, és a háztartások humántőke-eloszlását egyre normáljuk: $1=\int h H(d h)$, ahol az integrál $\left(\int\right)$ azt ragadja meg, hogy a humán tőkéket $(h)$ összegezzük. Jelölje $\bar{n}=\int h \bar{n}_{h} H(d h)$ az egyes háztartások humán tőkéjével súlyozott munkakínálatok átlagát, amelyet egyfajta aggregált munkakínálatként is felfoghatunk. Ekkor az adózás előtti bérjövedelme egy adott $h$ háztartásnak $t$-ik időperiódusban: $w_{t} h n_{h, t}$. A progresszív adózás esetén az átlagos és a marginális adókulcs különbözik. Heathcote et al. (2010) alapján feltesszük, hogy a marginális adókulcs konstans rugalmasság mellett reagál a nettó jövedelem változásaira. Az elaszticitást u-vel jelöljük, és a következő módon súlyozzuk a humántőke-felhalmozást is figyelembe vevő munkajövedelmet:

$$
L=w(\bar{n})^{1-\cup}\left(h \bar{n}_{h}\right)^{\cup}
$$

\section{Eltitkolt jövedelem és fehéredés}

Az eltitkolt jövedelmet a következő hüvelykujj-szabály alapján kalkuláljuk (a munkát-terhelő adókulcs egy adott értéke mellett, amit $\tau_{i}^{n}$-vel jelölünk):

$$
\breve{E}\left(\tau_{i}^{n}\right)=\epsilon L+\epsilon\left(\tau_{i}^{n}-\tau_{r e f}^{n}\right) L \phi
$$

ahol $\breve{E}\left(\tau_{i}^{n}\right)$ jelöli az eltitkolt jövedelmet egy adott munkát terhelő adókulcs esetén. $L$ jelöli a bér és a ledolgozott munkaórák szorzatát. $\tau_{\text {ref }}^{n}$ a referencia-adókulcsot jelenti. Az $\in$ az eltitkolt jövedelem arányát mutatja a referencia-adókulcs $\left(\tau_{i}^{n}=\tau_{r e f}^{n}\right)$ mellett. $\phi$ paraméter az eltitkolt jövedelem adóalapra vonatkozó érzékenységét segít kalibrálni.

Ezek alapján a bevallott jövedelem a tényleges jövedelem és az eltitkolt jövedelem különbségeként adódik:

$$
\dot{B}\left(\tau_{i}^{n}\right)=L-\breve{E}\left(\tau_{i}^{n}\right)
$$

A bevallott jövedelem és az adókulcs szorzata alapján számolható a befolyt adóbevétel:

$$
T_{i}^{n}=\dot{B}\left(\tau_{i}^{n}\right) \tau_{i}^{n}
$$

Ezek alapján a modell által implikált effektív adókulcs a következőképpen írható fel:

$$
\tau_{i, \text { effektiv }}^{n}=\frac{T_{i}^{n}}{\dot{B}_{i}}
$$


Az eltitkolt munkajövedelem figyelembevételét követően a háztartás költségvetési korlátja, a fizikaitőke- és a humántőke-felhalmozás egyenletei az alábbi módon írhatók fel:

$$
\begin{gathered}
\left(1+\tau_{t}^{c}\right) c_{t}+x_{t}+b_{t}=\left(1-\tau_{t}^{n}\right) \dot{B}_{t}+\breve{E}_{t}+\left(1-\tau_{t}^{k}\right)\left(d_{t}-\delta\right) k_{t-1}+R_{t-1}^{b} b_{t-1}+s_{t}+m_{t} \\
k_{t}=(1-\delta) k_{t-1}+x_{t} \\
h_{t}=\left(A q_{t} n_{t}+B\left(1-q_{t}\right) n_{t}\right)^{v} h_{t-1}^{1-v}+\left(1-\delta_{h}\right) h_{t-1}
\end{gathered}
$$

Az előző egyenletekben $s_{t}, k_{t}, x_{t}$, és $b_{t}$ jelöli a kormányzati transzfereket, fizikai tőkét, a fizikai tőkébe való beruházást és a kormányzati kötvényállományt. $A$ háztartás birtokolja a kormányzat által kibocsátott kötvényeket, és kamatot $\left(R_{t-1}^{b}\right)$ kap az előző időszaki kötvényállomány $\left(b_{t-1}\right)$ után. $m_{t}$ jelöli az külkereskedelmi mérleget (export-import), $d_{t}$ pedig a tőke bérleti díját. A munkát, tőkét és fogyasztást terhelő adórátákat $\tau^{n}, \tau^{k}, \tau^{c}$-vel jelöljük. $w_{t}$ jelöli a reálbért. $\delta$ jelöli a fizikai tőkeállomány amortizációs rátáját. $d_{t}-\delta$ azt jelenti, hogy a tőke adóalapjából az amortizációt le lehet vonni. A humántőke-felhalmozás egyenletében az $A$ és $B$ konstansokat jelöl, amelyek a munka hatékonyságának a javulását és a tanulást segítik kalibrálni. $\delta_{h}$ méri a szellemi tőke elavulását. Az $A$ paraméter értékét úgy választjuk meg, hogy $q$ - amely a munkára fordított idő aránya a munkára és tanulásra fordított időn belül 0,8 legyen. $B$ biztosítja, hogy $h=1$ az állandósult állapotban. $\left(1-\tau_{t}^{n}\right) \dot{B}_{t}$ mutatja a ténylegesen bevallott jövedelem utáni nettó bért, $\breve{E}_{t}$ pedig az eltitkolt jövedelem.

Ezen a ponton érdemes megjegyezni, hogy amikor a munkát, tőkét vagy a fogyasztást terhelő adókat változtatjuk - vagyis a Laffer-görbe mentén mozgunk - akkor a kormányzat költségvetési korlátját a transzferek változása fogja kiegyensúlyozni. Továbbá feltesszük, hogy az aggregált erőforráskorlát kiszámításakor - amely a háztartás és a kormányzat költségvetési korlátjának aggregálását jelenti - az eltitkolt jövedelmet egyfajta kormányzati transzferként fogjuk fel.

\section{Állam}

Az állam határozza meg a munkát és a tőkét terhelő, valamint a fogyasztási adókulcsokat, valamint a munkát terhelő adó progresszivitását. Az adókon kívül még államkötvények kibocsátásával jut forráshoz. Az állam a bevételeit részben közvetlen állami kiadásokra, részben a háztartásoknak nyújtott pénzügyi transzferekre fordítja, mely utóbbiak expliciten meg is jelennek a háztartások költségvetési korlátjában. A kormányzati kiadást GDP-arányosan állandónak feltételezzük, így az adókulcs-változtatások a kiadási oldalon elsősorban a háztartásoknak nyújtott transzferek mértékét változtatják. 
A kormányzat költségvetési korlátja a következő módon írható fel:

$$
g_{t}+s_{t}+R_{t-1}^{b} b_{t-1}=b_{t}+T_{t}
$$

A kormányzat költségvetési korlátjának jobb oldala mutatja a bevételeket, amik adókból $\left(T_{t}\right)$ vagy kötvények $\left(b_{t}\right)$ kibocsátásából származnak. A korlát bal oldala mutatja a kiadásokat, amelyek lehetnek: nem-produktív és a háztartás hasznosságát nem növelő kormányzati fogyasztás $\left(g_{t}\right)$, az előző időszaki kötvényállomány után fizetett kamatok $\left(R_{t-1}^{b} b_{t-1}\right)$ és a háztartásoknak juttatott transzferek $\left(s_{t}\right)$.

A kormányzat adóbevételei $\left(T_{t}\right)$ a következő módon összegződnek:

$$
T_{t}=\tau_{t}^{c} c_{t}+\tau_{t, \text { effektiv }}^{n} \dot{B}_{t}+\tau_{t}^{k}\left(d_{t}-\delta\right) k_{t-1}
$$

Vagyis a kormányzat a fogyasztást $\left(\tau_{t}^{c} c_{t}\right)$, a munkát $\left(\tau_{t, \text { effektiv }}^{n} \dot{B}_{t}\right)$ és a tőkét $\left(\tau_{t}^{k}\left(d_{t}-\delta\right) k_{t-1}\right)$ adóztatja.

Vállalat

A vállalat a tőke és a munka optimális megválasztásával maximalizálja a profitját:

$$
\max _{k_{t-1}, n_{t}} \pi_{t}=\max _{k_{t-1}, n_{t}}\left\{y_{t}-w_{t} n_{t}-d_{t} k_{t-1}\right\}
$$

ahol $y_{t}$ standard Cobb-Douglas-technológia: $y_{t}=\gamma^{t} k_{t-1}^{\theta}\left(h_{t-1} q_{t} n_{t}\right)^{1-\theta}$, ahol $\gamma$ jelöli a technológia determinisztikus trend szerinti növekményét. A termelési függvényben $\theta$ mutatja a fizikai tőke részarányát a termelésben, $1-\theta$ pedig a humán tőkével kiegészített munka részaránya a termelésben.

Egyensúlyban a háztartások maximalizálják a hasznosságukat, a vállalatok maximalizálják a profitjukat, míg a kormányzat úgy választja meg az adóbevételeit, hogy fedezze a kiadásait minden időpontban. Ez utóbbiból következik, hogy az állam adósságállománya állandó. Egyensúlyban a stabil növekedési pályán a változók konstans ütemben növekednek.

\section{Modellkalibrálás és megoldás}

A modell kalibrációját Magyarországra az 1. táblázat tartalmazza. Az $\eta, \varphi$ paramétereket az irodalomban standard értékekre állítjuk. Az egyensúlyi feltételeket és a tőke amortizációs rátáját $(\delta)$ használjuk a tóke termelésbeni részarányának bekalibrálásához $(\theta)$, amely 38 százalék körül van a vizsgált periódusban. Trabandt és Uhlig (2011) nyomán feltesszük, hogy a humán tőke a fizikai tőkével azonos ütemben amortizálódik: $\delta_{h}=\delta$. Az állandósult állapotbeli munkaóra (a teljes időkeret 25 százaléka Trabandt és Uhlig (2011)-hoz hasonlóan) bekalibrálását a k paraméterrel végezzük. A modell a gazdaság egyensúlyi állapotát tudja megragadni, ezért a kalibrálásához jellemzően a makrogazdasági változók 2007-2018-as időszakra jellemző átlagos értékét vettük figyelembe. A GDP-arányos tőkét $(k / y)$ a modell paraméterei 
és a tőke adókulcsa határozza meg. A magánberuházás és GDP-aránya $(x / y)$ egyensúlyban a GDP-arányos tőkeállomány, a tőke amortizációja és a gazdaság növekedési ütemének a függvényében 25 százalék, amely közel van az ablak-periódus átlagához (22 százalék) annak ellenére, hogy nem kalibráljuk. A kormányzati kiadás a GDP arányában $(g / y) 21$ százalék körül alakult a jelzett periódusban. A folyó fizetési mérleg és a GDP aránya $(\mathrm{m} / \mathrm{y})$ a 2007-2018-as periódusban átlagosan 0,5 százalék. A fogyasztás és GDP-aránya endogén módon adódik az aggregált erőforráskorlátból és a GDP 50 százalékára tehető a vizsgált periódussal összhangban. A GDP-arányos államadósság a vizsgált időszakban 75 százalék körül alakult.

\section{1. táblázat}

\section{A kalibrált paraméterek értékei}

\begin{tabular}{|c|c|c|c|}
\hline Paraméter & Szimbólum & Érték & Forrás \\
\hline Fizikai és humán tőke amortizációja & $\delta=\delta_{h}$ & 0,07 & Trabandt és Uhlig (2011) \\
\hline Tőke aránya a termelésben & $\theta$ & 0,38 & Trabandt és Uhlig (2011) \\
\hline Tanulás súlya a humántőke-felhalmozásban & $v$ & 0,5 & Trabandt és Uhlig (2011) \\
\hline Intertemporális elaszticitás inverze & $\eta$ & 2 & Trabandt és Uhlig (2011) \\
\hline Frisch-elaszticitás & $\varphi$ & 2 & Trabandt és Uhlig (2011) \\
\hline Restrikció & $\kappa$ & 3,46 & $\overline{q n}=0,25$ teljesül \\
\hline Diszkontfaktor & $\beta$ & 0,99 & $\begin{array}{l}\text { A hosszú távú kamat és } \\
\text { növekedési ütem által } \\
\text { implikált. }\end{array}$ \\
\hline $\begin{array}{l}\text { Eltitkolt jövedelem érzékenysége az adóalap } \\
\text { változására }\end{array}$ & $\phi$ & 0,05 & Clotfelter (1983) \\
\hline munkaidő/(munkára és tanulásra fordított idő) & $q$ & 0,8 & Trabandt és Uhlig (2011) \\
\hline $\begin{array}{l}\text { Az eltitkolt jövedelem aránya a teljes } \\
\text { munkajövedelmen belül }\end{array}$ & $\epsilon$ & 0,25 & Köllö (2010) \\
\hline Adórendszer progresszivitása & $\varepsilon$ & 0,08 & saját becslés \\
\hline Átlagos, referencia adókulcs & $\tau_{r e f}^{n}$ & 0,50 & Köllő (2010) \\
\hline Kormányzati kiadás/GDP & $\mathrm{g} / \mathrm{y}$ & 0,21 & 2007-2018 átlag \\
\hline Kormányzati adósság/GDP & $\mathrm{b} / \mathrm{y}$ & 0,75 & 2007-2018 átlag \\
\hline Nettó import/GDP & $\mathrm{m} / \mathrm{y}$ & 0,005 & 2007-2018 átlag \\
\hline
\end{tabular}

Az alkalmazott modell a humántőke felhalmozást is lehetővé tevő alap neoklasszikus modellhez képest explicite beépíti az adókulcs jövedelemeltitkolásra gyakorolt hatását, valamint a progresszív adóztatás lehetőségét. A fentieken túlmenően még kiemelt jelentősége van a modellben használt adókulcsok mértékének meghatározásának. Ezen összetevők kalibrálása során az alábbi feltételezésekkel éltünk: 


\section{Fehéredés}

A fehéredés kalibrálása során azt feltételezzük, hogy 50 százalékos adókulcs $\left(\tau_{r e f}^{n}\right)$ mellett a munkát terhelő adók adóalapjának átlagosan 25 százalékát eltitkolják (lásd Köllő 2010). Az adókulcs változtatásának bevallott jövedelemre gyakorolt hatásának kalibrálásánál azt feltételezzük, hogy a munka adókulcsának 4 százalékpontos csökkenése 5 százalékkal csökkenti az eltitkolt jövedelmet (lásd pl. Clotfelter 1983).

\section{Progresszivitás}

Az egykulcsos jövedelemadót megelőzően a munkát terhelő adó progresszivitásának becsléséhez a progresszivitás modellben való megjelenítésének módjával összhangban regresszáltuk a nettó jövedelmeket a teljes bérköltségen, a 2007-es járulékokat járulékfizetőnként tartalmazó adatbázison, Heathcote és szerzőtársaihoz (2010) hasonlóan:

$$
y^{\text {nettó }}=\text { constant }+(1-\varepsilon) y^{\text {teljes bérköltség }}
$$

Az előző egyenletben az $\varepsilon$ mutatja az adórendszer progresszivitását és ezáltal a redisztribúció mértékét. Amikor $\varepsilon=1$, akkor teljes újraelosztás van, míg $\varepsilon=0$ egykulcsos rendszert jelent. A fenti modellünkben $1-u$ felel meg a fenti regresszióban szereplő $\varepsilon$-nak. Becsléseink alapján az $\varepsilon$ értéke 0,08 . A regresszió bal és jobb oldali változói logaritmusban vannak, így $1-\varepsilon$ elaszticitásként értelmezhető, vagyis a bérköltség egy százalékos változása a nettó jövedelemben egy százaléknál kisebb változást idéz elő. ${ }^{4}$

\section{Effektív adóráták}

A modellben az effektív adókulcsokat a ténylegesen megfigyelt effektív adóráták alapján kalibráljuk. A becsült effektív adóráták az adott adónemből befolyó költségvetési adóbevételek, valamint az adóalap hányadosaként adódnak. A becsült adóráták így az adókedvezmények hatását is képesek megragadni. A munkát terhelő adóbevételek forrása a költségvetési zárszámadás. A munkát terhelő adó adóalapjaként a NAV által számított SZJA-adóalap és a hatályos munkáltatóijárulék-kulcsok felhasználásával meghatározott teljes bérköltséget használjuk. Az effektív tőkét terhelő, valamint a fogyasztási adókulcs kalibrálásához az Európai Bizottság (2019) számításait használjuk fel. A tőkeadó alapja a Bizottság módszertana által definiált tőkejellegű bevételek, míg a fogyasztási adó adóalapja a háztartások végső fogyasztása. A becsült effektív adórátákat a 2. ábra mutatja.

\footnotetext{
${ }^{4} \mathrm{~A}$ becsült regresszió:

$y^{\text {nettó }}=\underset{(0,0004)}{0,496}+\underset{(0,00002)}{0,922 y^{\text {teljes bérköltség }},}$

ahol a becsült együtthatók alatti értékek a sztenderd hibát jelölik.
} 


\section{2. ábra}

Effektív adókulcsok Magyarországon 2007 és 2017 között

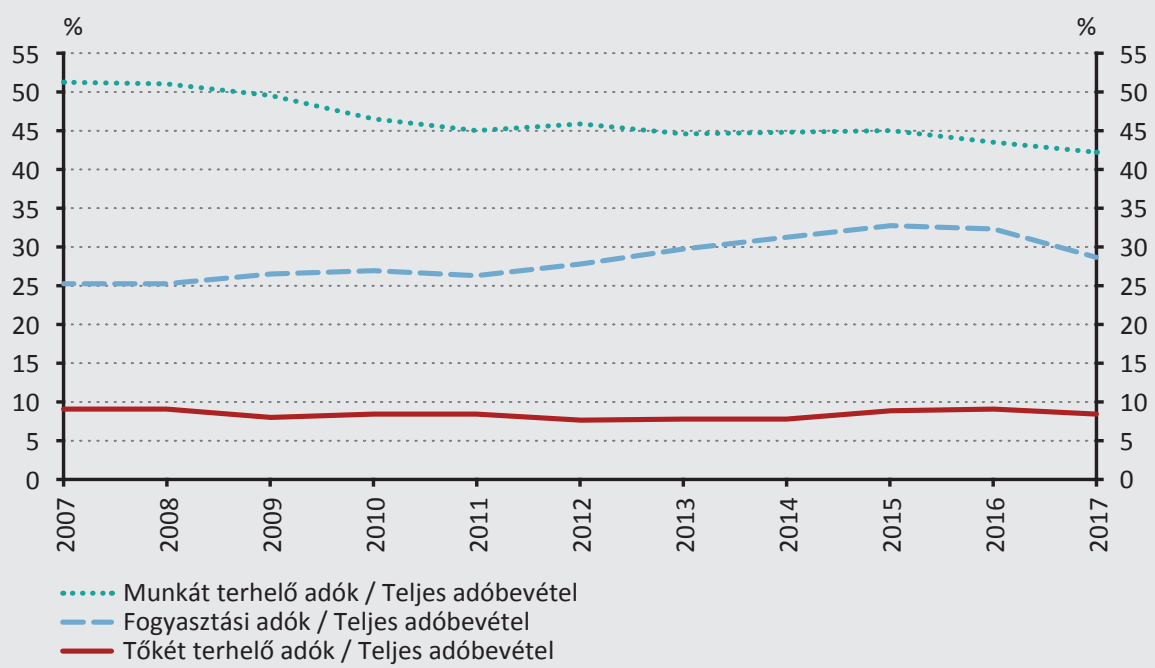

Forrás: Európai Bizottság Taxation Trends in the European Union címü kiadványa, NAV és költségvetési zárszámadás

Fontos kiemelni, hogy az általunk becsült munkát terhelő effektív adóráta alapja az adózók által bevallott adóalapok összege. Ennek megfelelően az adóelkerülés mértékének változása a munkát terhelő effektív adóráta becslését nem befolyásolja. Továbbá tekintettel arra, hogy az effektív adórátát a tényleges költségvetési bevételekből számítjuk, így egyik évről a másikra az effektív adóráta változásához számos tényező hozzájárulhat, nem csak az adószabályok változtatása. Hosszabb időszakot elemezve ugyanakkor az effektív adóráta változásában az adókulcsok és más adószabályok (pl. adókedvezmények) a meghatározók.

\section{A modell megoldása és szimulációk}

A tanulmány célja a Laffer-görbe becslése Magyarországra. Ennek érdekében a modell egyensúlyi állapotait a munkát terhelő adókulcs minden egyes értékére numerikus módszerrel meghatározzuk (Newton-féle módszerrel). A különféle munkát terhelő adókulcsok mellett realizált költségvetési bevételek adják meg a Laffer-görbét.

A kalibrált modellt adópolitikai lépések hatásának szimulációjához is felhasználjuk. Tekintettel arra, hogy a kalibrált modell egy egyensúlyi állapotban lévő gazdaság jellemzőit képes visszaadni, így a szimulációk során a modellparamétereket az adókulcsokra és progresszivitásra vonatkozó feltételezésektől eltekintve nem változtatjuk. A modellben két időszakot vizsgálunk: i) 2007-2011 közötti munkát terhelő adócsökkentéseket, illetve ii) egy hipotetikus 6 százalékpontos munkát terhelő adócsökkentést, amelyet a 2018-as effektív adókulcsokhoz viszonyítunk. A szimulációk 
során az adóváltoztatások statikus (változatlan adóalap mellett) és dinamikus hatásának (növekvő adóalapot figyelembe véve) összevetésével azt vizsgáljuk, hogy az adócsökkentések milyen mértékben voltak önfinanszírozók a gazdaság élénkülése következtében.

A szimulációk során elemezzük a humántőke-felhalmozást megengedő és humántőke-felhalmozás nélküli modellváltozatot is. Ennek oka, hogy az adóváltoztatás humántőke-felhalmozáson keresztül jelentkező hatása csak hosszú távon realizálódik, így a két modellváltozat alapján kapott eredmények értelmezhetőek az adóváltoztatás középtávú és hosszú távú hatásaként.

\section{Eredmények}

Az ismertetett modell segítségével megbecsüljük a munkát terhelő adókulcs Laffer-görbéjét a magyar gazdaságra a humántőke-felhalmozást tartalmazó (hosszú távú) és nem tartalmazó (középtávú) modellváltozattal. A becsült görbéket mutatja a 3. ábra. A 2018-as adószerkezet alapján becsült Laffer-görbe a középtávú modellváltozat alapján 55 százalék, míg a hosszú távú modell alapján 40 százalék körüli adóék (teljes bérköltségre vetített adók és járulékok) mellett éri el a maximumát. Érdemes felhívni a figyelmet arra, hogy a 2010-es gazdasági fordulatot megelőzően a maximális marginális adókulcs a Laffer-görbe csúcsától jobbra, vagyis a görbe negatív meredekségű szakaszára esett. A 2010 utáni adóreformot követően a marginális adókulcs átkerült a csúcstól balra levő pozitív meredekségű szakaszra, így az adórendszer hatékonysága jelentősen javult.

A magyar gazdaságra kalibrált modell segítségével szimulációkat végeztünk annak érdekében, hogy megbecsüljük a munkát terhelő adókulcs csökkentésének hatását a költségvetés bevételeire. Azt a kérdést kívánjuk megválaszolni, hogy egy adott kiinduló állapotból végrehajtott adócsökkentés milyen mértékben önfinanszírozó. Az önfinanszírozást az adócsökkentés statikus és dinamikus hatásának eredőjeként a következőképpen kalkuláljuk: (statikus hatás - dinamikus hatás)/statikus hatás. A statikus hatás az adóalapok változatlansága mellett áll elő, míg a dinamikus hatása esetén mindhárom (munka, fogyasztási és tőke) adóalap változik. Az önfinanszírozás tehát a költségvetés teljes adóbevételére vonatkozik, a munkát terhelő adóbevétel mérséklődését részben a tőkét terhelő és a fogyasztási adóalapok bővülése ellensúlyozza.

A 4. ábra mutatja a 2007 és 2011 közötti, munkát terhelő hatását az adóbevételekre a humántőke-felhalmozást nem tartalmazó modellváltozat alapján. 2007 és 2011 között az adócsökkentés hatására - változatlan adóalap mellett - a teljes adóbevé- 


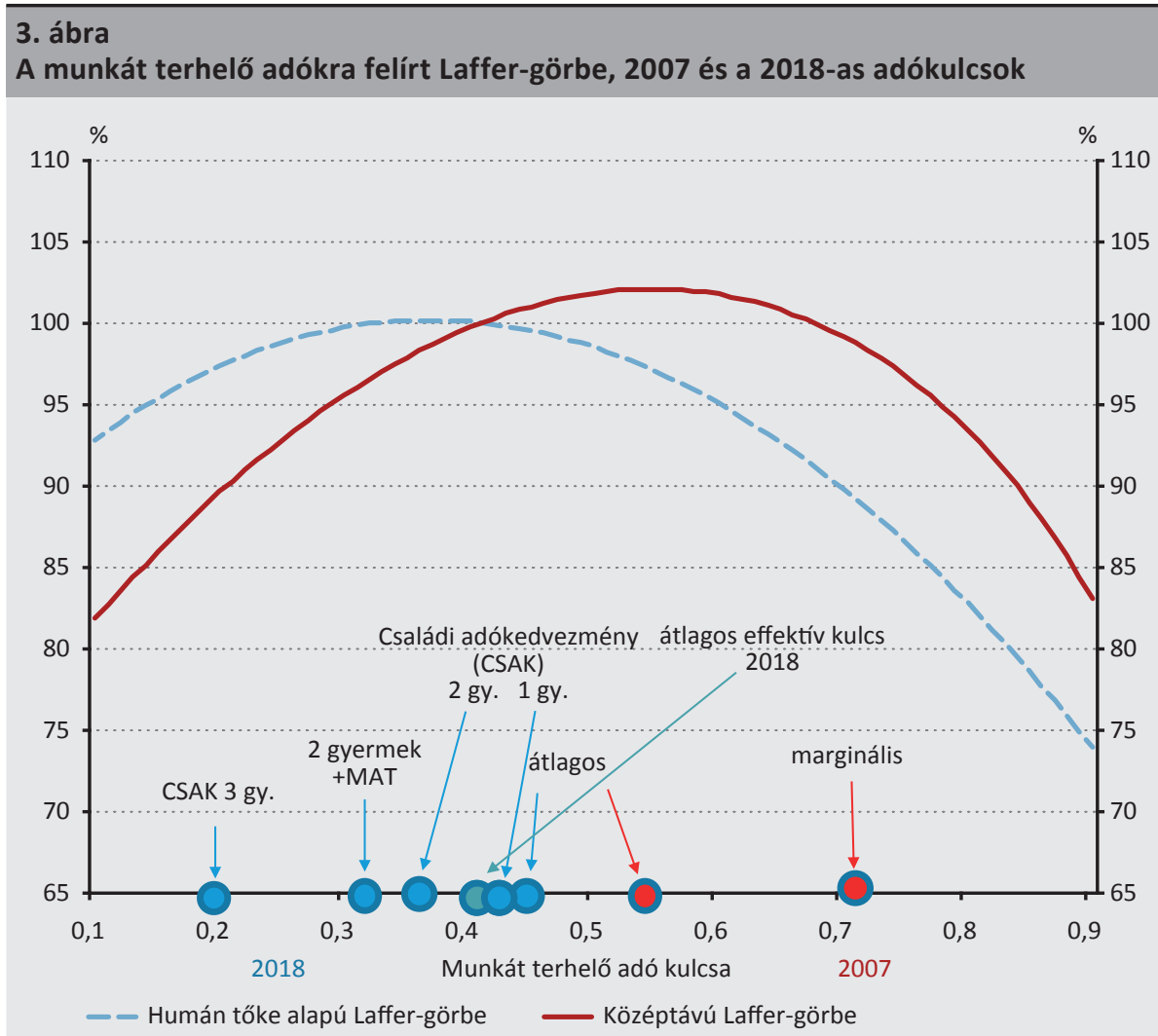

Megjegyzés: A teljes adóbevétel 100 százalékra van normálva a 2018-as átlagos effektív munka adókulcsánál. A kék és piros színü körök az átlagbérnél számitott adókulcsokat mutatják különböző, igénybe vehetö kedvezmények mellett. Az átlagos adókulcs az átlagbért kereső, de kedvezményt igénybe nem vevő adózóra vonatkozik. A Laffer-görbét a 2018-as adószerkezet alapján becsültük.

tel 6 százalékkal ${ }^{5}$ csökkent volna (közvetlen hatás). Az alacsonyabb adók azonban élénkítik a gazdasági teljesítményt, beleértve különösen a foglalkoztatást és ezen keresztül a fogyasztást, ami az adóalapok (munka, tőke és fogyasztási adóbevételek) bővülését vonja maga után (lásd többletmunka, többlettőke és többletfogyasztás a 4. ábrán). Az adóalapok bővüléséből eredő többletbevétel már középtávon is nagyrészt ellensúlyozza a kezdeti (statikusan számolt) bevételcsökkentő hatást. Ebben mindegyik adóalap bővülése jelentős szerepet játszik, és a munkát terhelő adóbevételeket a munkajövedelmek fehéredése is jelentősen növeli. Emiatt az adóbevételek középtávon összességében csak 1,4 százalékkal csökkennek. A szimuláció alapján tehát az 2007 és 2011 közötti adócsökkentés már középtávon is közel 80 százalékban önfinanszírozó volt.

\footnotetext{
${ }^{5}$ A munkát terhelő adóbevételeknek a súlya 2007-ben 49 százalék volt az adóbevételeken belül. Egyszerű számítással adódik, hogy az 51-ről 45 százalékra való munkaadókulcs-csökkentésnél a statikus hatás szerint az adóbevétel $((51-45) / 51) \cdot 100 \cdot 0,49 \approx 6$ százalékkal esik.
} 


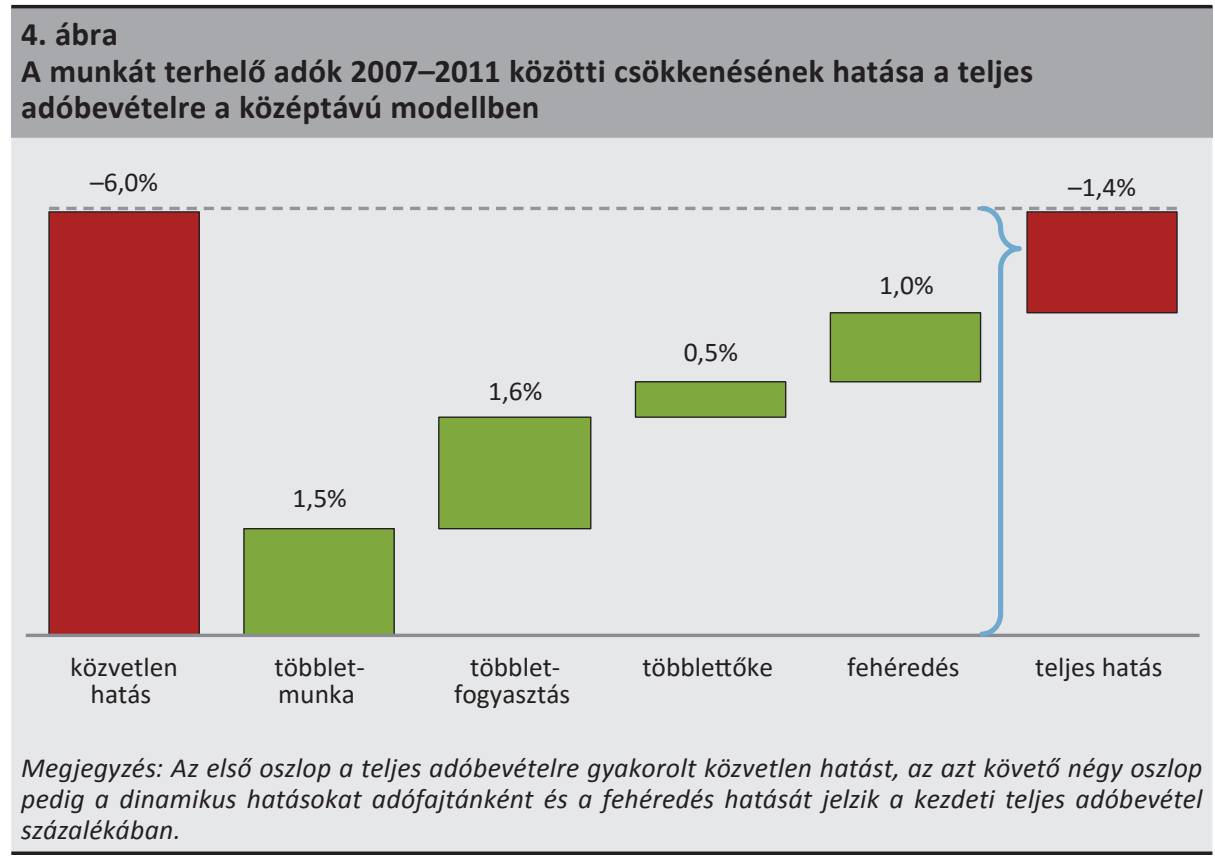

A számításokat elvégeztük a humántőke-felhalmozást is megengedő modellváltozat segítségével is. Ennek alapján az adócsökkentés hosszú távú bevételnövelő hatása több mint ellensúlyozza a kezdeti bevételcsökkenést: hosszú távon a költségvetés bevételei összességében emelkednek (1,4 százalékkal) az adócsökkentés következtében (5. ábra). Ez annak köszönhető, hogy a modell megragadja azt a hatást is, hogy a foglalkoztatást terhelő adókulcsok csökkenése következtében jobban megéri a humán tőkébe fektetni, és a munkavállalók (illetve a munkáltatók) élnek is ezzel. A humán tőke magasabb színvonala értelemszerűen növeli a potenciális elérhető gazdasági teljesítményt, azaz a középtávú modellhez képest is növeli az adóalapokat.

A múltbeli adócsökkentés hatásának becslésén túlmenően szimuláltuk egy lehetséges jövőbeni személyijövedelemadó-kulcs csökkentés hatását is a 2018-as adatok alapján. Szimulációnk során egy 6 százalékpontos személyijövedelemadó-kulcs csökkentés hatását elemezzük. A középtávú hatásokat megragadó modellünk alapján a gazdaságélénkítő hatás miatt a teljes adóbevétel 1,7 százalékkal csökken, az önfinanszírozás mértéke tehát középtávon közel 66 százalék (6. ábra). A 2007-2011 időszakra becsültnél kisebb önfinanszírozási arányt az magyarázza, hogy a 2018-as adócsökkentés alacsonyabb adókulcsról indul, ahol a Laffer-görbe meredekebb. 


\section{5. ábra \\ A munkát terhelő adók 2007-2011 közötti csökkentésének hatása a teljes adóbevételre a humántőke-alapú (hosszú távú) modellben}

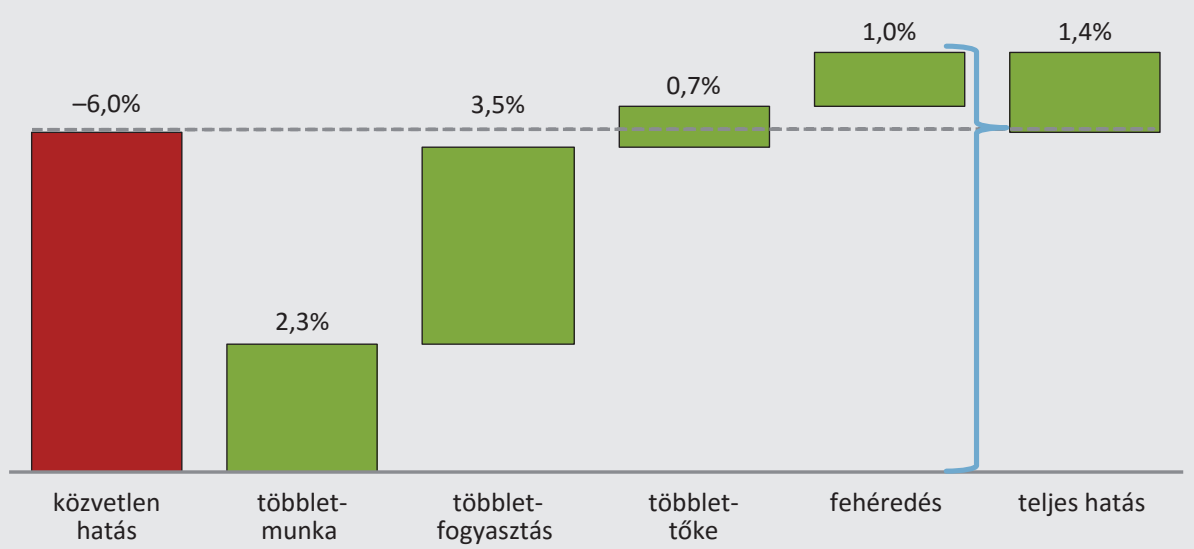

Megjegyzés: Az első oszlop a teljes adóbevételre gyakorolt közvetlen hatást, az azt követő négy oszlop pedig a dinamikus hatásokat adófajtánként és a fehéredés hatását jelzik a kezdeti teljes adóbevétel százalékában.

\section{6. ábra \\ A személyijövedelemadó-kulcs 15-ről 9 százalékra csökkentésének hatása a teljes adóbevételre a középtávú modellben}

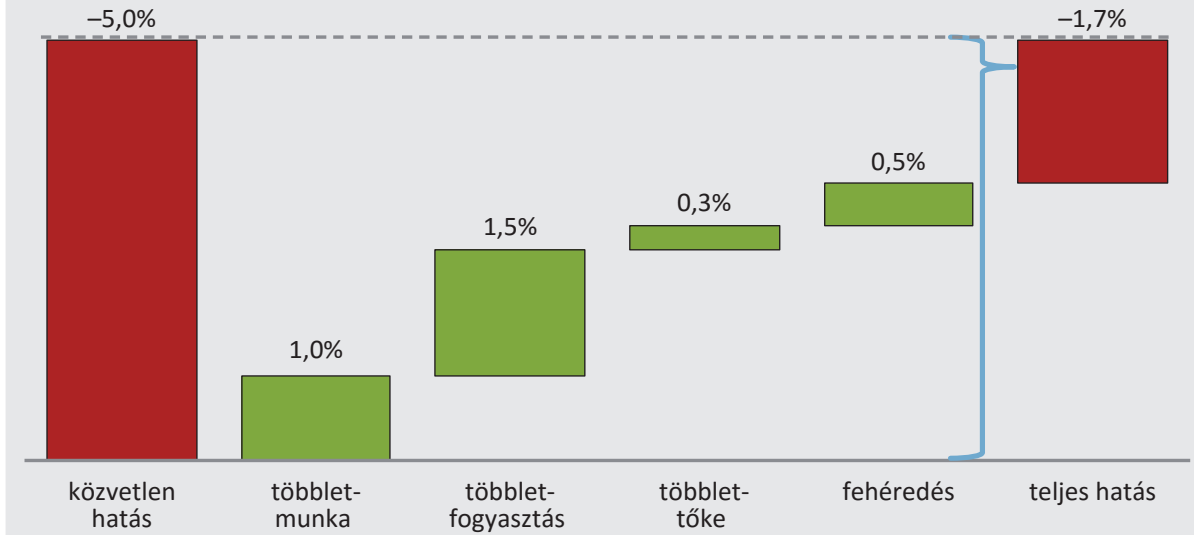

Megjegyzés: Az első oszlop a teljes adóbevételre gyakorolt közvetlen hatást, az azt követő négy oszlop pedig a dinamikus hatásokat adófajtánként és a fehéredés hatását jelzik a kezdeti teljes adóbevétel százalékában. 
A humántőke-felhalmozást is figyelembe vevő, hosszú távú modellben a 2018-ban induló, feltételezett adócsökkentés - a 2007-2011-es adócsökkentéshez hasonlóan - az adóalapok jelentős bővülését eredményezi, így a teljes adóbevétel csak 0,3 százalékkal csökken (7. ábra). Ennek megfelelően az önfinanszírozás mértéke továbbra is magas, 93 százalék.

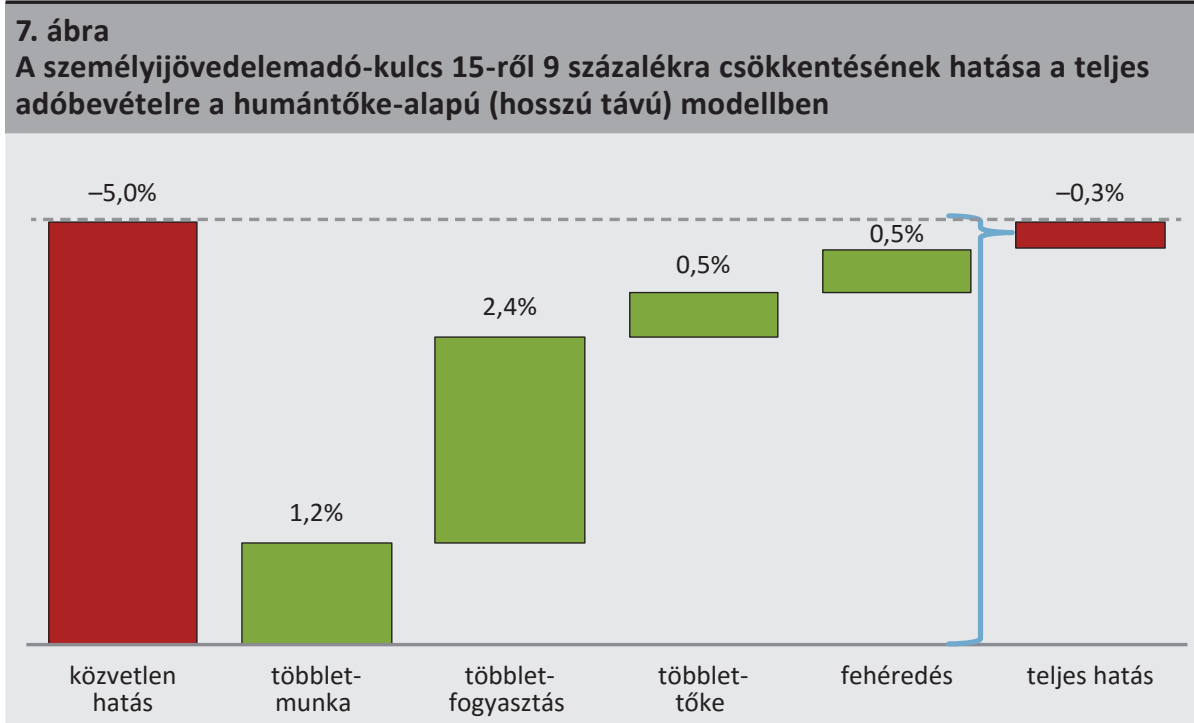

Megjegyzés: Az első oszlop a teljes adóbevételre gyakorolt közvetlen hatást, az azt követő négy oszlop pedig a dinamikus hatásokat adófajtánként és a fehéredés hatását jelzik a kezdeti teljes adóbevétel százalékában.

Fontos felhívni a figyelmet arra, hogy a szimulációk átlagos (azaz sem nem túl feszes, sem nem túl laza) munkapiaci környezetet feltételeznek kiinduló állapotban. Amenynyiben például az adócsökkentést megelőzően a munkapiacot jelentős munkaerőhiány jellemzi, akkor az adócsökkentés kevésbé tudja emelni a foglalkoztatottságot, így az adóbevételekre gyakorolt közvetett hatása a fentebb bemutatottnál kisebb.

Végezetül érdemes összevetni az eredményeinket más tanulmányokéval. A korábbi, más gazdaságokra becsült Laffer-görbék bevételt maximalizáló adókulcsa jellemzően magasabb az általunk becsültnél a humántőke felhalmozást megengedő és az anélküli modellváltozatokban is. Ennek oka, hogy az általunk alkalmazott modellbe beépítettük az adókulcs-változtatásnak az eltitkolt jövedelem arányára gyakorolt hatását, így a mi modellünkben az adókulcs változtatásának nagyobb a munkát terhelő adó adóalapjára gyakorolt hatása. 
Az empirikus tanulmányok eredményeivel való összevetéshez figyelembe kell venni, hogy ezek a tanulmányok jellemzően a munkát terhelő adó csökkentésének a munkát terhelő adó bevallott adóalapjára gyakorolt hatását számszerúsítik az adócsökkentést követő néhány évben. Ez a hatás leginkább a középtávú modellünkben az adócsökkentésnek a munkaórák emelkedésén (lásd többletmunka oszlop a 4-7. ábrákon), valamint a jövedelmek fehéredésén (lásd fehéredés oszlop a 4-7. ábrákon) keresztül jelentkező adóalap-növelő hatásával feleltethető meg. Eredményeink szerint a 2007-2011 között az adóbevételt statikusan egy egységgel mérséklő adócsökkentés dinamikusan 0,4 egységgel ((többletmunka+fehéredés)/ közvetlen hatás), míg egy 2018-ban induló potenciális adócsökkentés 0,3-mal növelné a munkát terhelő adóbevételt. Az értékek közel állnak az empirikus tanulmányok becsléseihez. A 2007-2011 közötti időszakra vonatkozó magasabb értéket a magas magyar adókulcs magyarázza az adócsökkentés előtt.

\section{7. Összegzés}

Tanulmányunkban egy magyar gazdaságra kalibrált egyensúlyi modell segítségével megbecsültük a munkát terhelő adókulcs Laffer-görbéjét egy humántőke-felhalmozás nélküli és egy humántőke-felhalmozást lehetővé tevő modellváltozatban. Az első modellváltozat a munkát terhelő adókulcs változtatásának középtávú, a második a hosszú távú hatásait képes megragadni. Az alkalmazott közgazdasági modell Trabandt és Uhlig (2011) tanulmányán alapul, melyet kibővítettünk az adókulcsok szintje és az eltitkolt jövedelmek nagysága közötti összefüggéssel.

Eredményeink alapján a bevételt maximalizáló adókulcs a középtávú modellben 55 százalék, míg a hosszú távú modellben 40 százalék körüli, s a maximális marginális adókulcs a 2010 utáni adóreformot követően került át a Laffer-görbe csúcsától balra elhelyezkedő, pozitív meredekségű szakaszra, így az adórendszer hatékonysága jelentősen javult.

A magyar gazdaságra kalibrált modell segítségével megbecsültük a 2007-2011 közötti adócsökkentés hatását a költségvetés bevételeire. Eredményeink szerint a munkavállalást ösztönző adócsökkentés középtávon közel 80 százalékban, míg hosszú távon teljes mértékben önfinanszírozó volt. A 2018-as munkát terhelő adókulcs további csökkentése számításaink szerint szintén nagymértékben önfinanszírozó: középtávon 66, míg hosszú távon 93 százalékos a megtérülése. 


\section{Felhasznált irodalom}

Akgun, O. - Bartolini, D. - Cournède, B. (2017): The capacity of governments to raise taxes. OECD Economics Department Working Papers, No. 1407. https://doi. org/10.1787/6bee2df9-en

Baksay Gergely - Palotai Dániel (2017): Válságkezelés és gazdasági reformok Magyarországon, 2010-2016. Közgazdasági Szemle, 64(7-8): 698-722. https://doi. org/10.18414/KSZ.2017.7-8.698

Clotfelter, Ch. T. (1983): Tax Evasion and Tax Rates: An Analysis of Individual Returns. The Review of Economics and Statistics, 65(3): 363-373. https://doi.org/10.2307/1924181

Európai Bizottság (2019): Taxation trends in the European Union: 2019 edition. Taxation trends 2019. Directorate General Taxation and Customs Union, European Commission.

Feldstein, M. (1995): The Effect of Marginal Tax Rates on Taxable Income: A Panel Study of the 1986 Tax Reform Act. Journal of Political Economy, 103(3): 551-572. https://doi. org/10.1086/261994

Féve, P. - Matheron, J. - Sahuc, J.-G. (2018): The Horizontally S-Shaped Laffer Curve. Journal of the European Economic Association 16(3): 857-893. https://doi.org/10.1093/jeea/ jvx027

Floden, M. - Lindé, J. (2001): Idiosyncratic Risk in the United States and Sweden: Is There a Role for Government Insurance? Review of Economic Dynamics, 4(2): 406-437. https:// doi.org/10.1006/redy.2000.0121

Heathcote, J. - Storesletten, K. - Violante, G. (2010): Redistributive Taxation in a PartialInsurance Economy. Slides.

Ireland, P. (1994): Supply-side economics and endogenous growth. Journal of Monetary Economics, 33(3): 559-571. https://doi.org/10.1016/0304-3932(94)90043-4

Jongen, E. - Stoel, M. (2019): The Elasticity of Taxable Labour Income in the Netherlands. IZA Discussion Papers 12090, Institute of Labor Economics (IZA). https://doi.org/10.1007/ s10645-019-09349-7

King, R. - Rebelo, S. (1999): Resuscitating Real Business Cycles. In: Taylor, J.B. - Woodford, M. (Eds.): Handbook of Macroeconomics, 1B: 927-1007. https://doi.org/10.1016/S15740048(99)10022-3

Kleven, H. J. - Schultz, E. A. (2014): Estimating Taxable Income Responses Using Danish Tax Reforms. American Economic Journal: Economic Policy, 6(4): 271-301. https://doi. org/10.1257/pol.6.4.271 
Köllő János (szerk.) (2010): A kérdőíves felvételekben megfigyelt, de be nem jelentett munkából eredő torzítás. In: Torzítanak-e a diplomások bérelőnyére vonatkozó adatok? Kutatási beszámoló OFA K-2008/F-8341

Matolcsy György - Palotai Dániel (2018): A magyar modell - A válságkezelés magyar receptje a mediterrán út tükrében. Hitelintézeti Szemle, 17(2): 5-42. http://doi.org/10.25201/ HSZ.17.2.542

MNB (2018): Versenyképességi jelentés. Magyar Nemzeti Bank, Budapest.

Novalez, A. - Ruiz, J. (2002): Dynamic Laffer Curves. Journal of Economic Dynamics and Control, 27(2): 181-206. https://doi.org/10.1016/S0165-1889(01)00031-8

Nutahara, K. (2015): Laffer curves in Japan. Journal of the Japanese and International Economies, 36(C): 56-72. https://doi.org/10.1016/j.jjie.2015.02.002

Saez, E. - Slemrod, J. - Giertz, S. H. (2012): The Elasticity of Taxable Income with Respect to Marginal Tax Rates: A Critical Review. Journal of Economic Literature, 50(1): 3-50. https:// doi.org/10.1257/jel.50.1.3

Schmitt-Grohe, S. - Uribe, M. (1997): Balanced-Budget Rules, Distortionary Taxes, and Aggregate Instability. Journal of Political Economy, 105(5): 976-1000. https://doi. org/10.1086/262101

Trabandt, M. - Uhlig, H. (2011): The Laffer curve revisited. Journal of Monetary Economics, 58(4): 305-327. https://doi.org/10.1016/j.jmoneco.2011.07.003

Trabandt, M. - Uhlig, H. (2012): How do Laffer curves differ across countries? NBER Working Paper No. 17862. https://doi.org/10.3386/w17862

Wanninski, J. (1978): Taxes, revenues, and the Laffer curve. The Public Interest, 50: 3-16. 


\section{Melléklet}

\section{2. táblázat}

A munkát terhelő, effektív adórátát érintő fontosabb adóintézkedések 2007 és 2018 között

2007 • Az SZJA 18 százalékos kulccsal adózó adóalapja 1,7 millió forintra nőtt. Az 1,7 millió Ft feletti jövedelmeket 36 százalékos adókulcs terheli.

- 2006-ról 2007-re a nyugdíjbiztosítási járulék 18-ról 21 százalékra nőtt.

- A munkavállalók által fizetett pénzbeni egészségbiztosítási járulék 3 százalékra nőtt 2 százalékról.

2008 - A foglalkoztató által fizetett járulékkulcs annyival csökkent, mint amennyire a foglalkoztatott általi kulcsok nőttek, vagyis összességében nem volt változás.

2009 • Az SZJA 18 százalékos kulccsal adózó adóalapja 1,9 millió forintra nőtt.

- A természetbeni egészségbiztosítási járulék 4,5 százalékról 1,5 százalékra csökkent az akkori minimálbér kétszeresének megfelelő járulékalapig.

- A korkedvezmény-biztosítási munkáltatói járulék 50 százalékát vállalta át a központi költségvetés, a korábbi 75 százalékkal szemben.

2010 - SzıA kulcsa 18 százalékról 17 százalékra csökkent és a a 17 százalékos kulcs összevont adóalapjának a plafonja 5 millió forintra emelkedett.

- Az 5 millió forint feletti jövedelmek kulcsa 36 százalékról 32 százalékra csökkent.

- A korkedvezmény-biztosítási munkáltatói járulék 25 százalékát vállalta át a központi költségvetés, a korábbi 50 százalékkal szemben.

- A magánnyugdíjpénztári tagdíj 0 százalékra csökkent, a magánnyugdíjpénztári tagok nyugdíjjáruléka 1,5 százalékról 9,5 százalékra nőtt.

- Az SZJA adóalapja a jövedelem adóalap-kiegészítéssel (27 százalékkal) megnövelt összege.

- A munkaerőpiaci járulék 3 százalékról 1 százalékra csökkent.

2011 - Az SzJA két kulcsa egységesen 16 százalékra csökkent.

- A munkavállalói nyugdíjjárulék 9,5 százalékról 10 százalékra nőtt.

- Bővültek a családi adókedvezmények (CSAK): egy vagy két gyerek után (gyermekenként) a kedvezmény összege 10 ezer Ft, három gyerek után (gyermekenként) 33 ezer forint.

\begin{tabular}{|c|c|}
\hline 2012 & $\begin{array}{l}\text { - Az összevont adóalap kiegészítést a jövedelem } 2 \text { millió } 424 \text { ezer forintot meg nem haladó része } \\
\text { után nem kellett megállapítani, e fölött } 27 \text { százalékos mértékkel kellett megállapítani. } \\
\text { - A biztosított által fizetett pénzbeni egészségbiztosítási járulék 2-ről } 3 \text { százalékra nőtt. }\end{array}$ \\
\hline 2013 & $\begin{array}{l}\text { - Szuperbruttósítás eltörlése a havi bruttó } 202 \text { ezer forintot meghaladó jövedelmek esetén. } \\
\text { - A járulékfizetési felső határ megszűnt a nyugdíjárulék esetén. } \\
\text { - Bevezetésre került a Munkahelyvédelmi Akcióterv (MAT). }\end{array}$ \\
\hline 2014 & $\begin{array}{l}\text { - A házastársak összesített személyi jövedelemadója mellett a } 7 \text { százalékos egészségbiztosítási } \\
\text { és a } 10 \text { százalékos nyugdíjjárulékból is levonható lett a családi adókedvezmény (CSAK). }\end{array}$ \\
\hline 2016 & $\begin{array}{l}\text { - Csökkent a személyi jövedelemadó } 15 \text { százalékra. } \\
\text { - A két gyerek után igénybe vehető CSAK gyermekenként } 10 \text { ezerről 12,5 ezerre nőtt. }\end{array}$ \\
\hline 2017 & $\begin{array}{l}\text { - A szociális hozzájárulási adó csökkent } 22 \text { százalékra. } \\
\text { - A két gyerek után igénybe vehető CSAK gyermekenként 12,5 ezerről } 15 \text { ezerre nőtt. }\end{array}$ \\
\hline 2018 & $\begin{array}{l}\text { - A szociális hozzájárulási adó csökkent 19,5 százalékra. } \\
\text { - A kétgyermekesek kedvezménye } 15 \text { ezerről 17,5 ezer forintra emelkedett. }\end{array}$ \\
\hline
\end{tabular}

